Article

\title{
Analysis of the Development of the Electromobility Market in Poland in the Context of the Implemented Subsidies
}

\author{
Ewelina Sendek-Matysiak ${ }^{1, *}$ and Zbigniew Łosiewicz $^{2}$ \\ 1 Faculty of Management and Computer Modeling, Kielce University of Technology, al. \\ TysiącleciaPaństwaPolskiego 7, 25-314 Kielce, Poland \\ 2 Department of Maritime Technology, West Pomeranian University of Technology in Szczecin, al. Piastów 41, \\ 71-065 Szczecin, Poland; zbigniew.losiewicz@zut.edu.pl \\ * Correspondence: esendek@tu.kielce.pl
}

Citation: Sendek-Matysiak, E.;

Łosiewicz, Z. Analysis of the

Development of the Electromobility Market in Poland in the Context of the Implemented Subsidies. Energies 2021, 14, 222. https://doi.org/ $10.3390 /$ en14010222

Received: 25 November 2020 Accepted: 29 December 2020 Published: 4 January 2021

Publisher's Note: MDPI stays neutral with regard to jurisdictional clai$\mathrm{ms}$ in published maps and institutional affiliations.

Copyright: (C) 2021 by the authors. Licensee MDPI, Basel, Switzerland. This article is an open access article distributed under the terms and conditions of the Creative Commons Attribution (CC BY) license (https:// creativecommons.org/licenses/by/ $4.0 /)$.

\begin{abstract}
The flagship project in this area in Poland is the Electromobility Development Program, one of the strategic documents of which is the Act on Electromobility and Alternative Fuels of 11 January 2018, which includes a system of benefits aimed at influencing consumer behaviors towards the choice of electric vehicles. According to the decision-makers, its implementation is expected to result in the achievement of a number of goals, among others, 1 million of such vehicles are forecast to be present at the national level in 2025. The intention of the authors is to analyze the progress in the development of electromobility in Poland, in the areas such as the market of electric cars, charging infrastructure, with an indication of whether the actions that are implemented by the legislator, i.e., guidelines on where and in what quantities charging stations dedicated to such vehicles are to be established, subsidies in the form of the possibility of driving on the lanes designed for buses, subsidies for the purchase of such vehicles intensify the development of electromobility in the country. The considerations were carried out for cars powered exclusively by electricity, i.e., BEV (Battery Electric Vehicle) type, category M1. Cars in this category represent the largest share of the automotive market in Poland-over 75\%. The utilitarian value of this research may be supported by the fact that the example of Poland and its problems concerning the discussed issue may be a source of preliminary analysis for other countries of the European Union.
\end{abstract}

Keywords: electric car; electromobility; charging station; subsidies

\section{Introduction}

The development of zero- and low-carbon transport is one of the priorities of the European Union environmental policy. In the Europe 2020 Communication: Strategy for smart, sustainable, and inclusive growth [1] one of the seven most important lead projects is the Flagship Project: A Resource-efficient Europe. The aim of the project is to support changes towards a low-carbon and resource-efficient economy, decoupling economic growth from the use of resources and energy, reducing $\mathrm{CO}_{2}$ emissions, increasing competitiveness, and increasing energy security.

The need to develop the infrastructure of alternative fuels in transport is clearly emphasized in the European Commission's White Paper of 28 March 2011 entitled "Roadmap to a Single European Transport Area-Towards a competitive and resource efficient transport system" [2]. The document calls for a reduction of transport dependence on petroleum. In addition, it is assumed to decrease greenhouse gas emissions from transport by $60 \%$ by 2050 compared to 1990.

In order to unify and harmonize the rules of building infrastructure for the use of alternative fuels within the Community, Directive 2014/94/EU of the European Parliament and of the Council of 22 October 2014 on the development of alternative fuel infrastructure was adopted. Article 3 of the Directive states that each Member State must develop a 
national policy framework for market development with regard to alternative fuels in the transport sector and the development of appropriate infrastructure [3].

In 2016, the Commission also presented a European strategy for low-carbon mobility [4], which states that greenhouse gas emissions from the transport sector must be reduced to at least $60 \%$ below 1990 levels and be further reduced consistently to zero.

The strategy includes, among other things, activities in the field of:

- increasing the use of low-carbon alternative energy sources for transport, including the development of alternative fuel infrastructure,

- $\quad$ transition to emission-free modes of transport (including the development of R\&D works).

At the national level, the key document in the area of Poland's medium- and long-term economic policy is the Strategy for Responsible Development until 2020 (with a perspective until 2030), and its flagship project is the Electromobility Development Program.

The strategy assumes an increase in cohesion in the social, economic, environmental, and territorial dimension by concentrating legal, institutional and investment activities on three objectives:

1. sustainable economic growth based increasingly on knowledge, data and organizational excellence;

2. socially sensitive and territorially sustainable development;

3. effective state and institutions for growth and social and economic inclusion.

The strategy underlines the importance of interventions in horizontal areas such as human and social capital, digitization, transport, energy, environment, and national security. The so-called development pillars, adopted by the Council of Ministers, are to be achieved through the implementation of key initiatives, defined as flagship and strategic projects. One of the pillars of the country's development is the development of technology. It is to determine the level of innovation in the economy, and this is to be influenced by the broadly understood development of the energy sector, from the search for new energy sources and ways of using them, through increasing the efficiency of energy production and mutual integration of sources, to safe and effective delivery of energy to the industry and households. Innovations in the energy sector are to concern both thermal and electric energy storage technologies, synergy of energy and telecommunication infrastructure, gradual diversification of fuel structure [5].

Among the adopted strategic projects, it is worth mentioning the Electromobility Development Program, the framework of which was defined in the Act of 22 February 2018 on Electromobility and Alternative Fuels, which, within the scope of its regulation, implements Directive 2014/94/EU of the European Parliament and of the Council of 22 October 2014 on the development of alternative fuel infrastructure. In its nature, the act is a comprehensive regulation in this area of state activity, defining the principles of development and functioning of the infrastructure of alternative fuels, obligations of public entities in the scope of development of the infrastructure of alternative fuels, information obligations in the scope of alternative fuels, conditions of functioning of clean transport zones and national framework for the policy of development of the infrastructure of alternative fuels, as well as the manner of their implementation [6].

The assumed objectives of the act are, among others: development of the electromobility industry, introduction of incentives for the development of innovative energy technologies, stimulation of activity of science and research centers and enterprises, setting common priorities and coordination of activities of government administration and local governments, influence on consumer behaviors towards the choice of low-carbon transport sources, coordination of activities related to the development of transport infrastructure (cars, fleets for public transport, and charging stations).

According to the forecasts of the Ministry of Energy, the implementation of the above actions in the field of the automotive market is to result in accomplishing the following objectives: 
$\checkmark \quad$ in 2020, in 32 selected agglomerations, 50,000 electric vehicles will be on the roads and 6000 normal charging power points will be created (so-called free charging points with a power not exceeding $3.68 \mathrm{~kW}$ ) and 400 high charging power points will be created;

$\checkmark \quad$ in 2025, 1 million electric vehicles are forecast to function at the national level [7].

Such a large share of electric cars in the automotive market in the country may undoubtedly contribute to the elimination of air pollution problems (Figure 1), to which inhabitants of large urban agglomerations are particularly exposed [8-10].

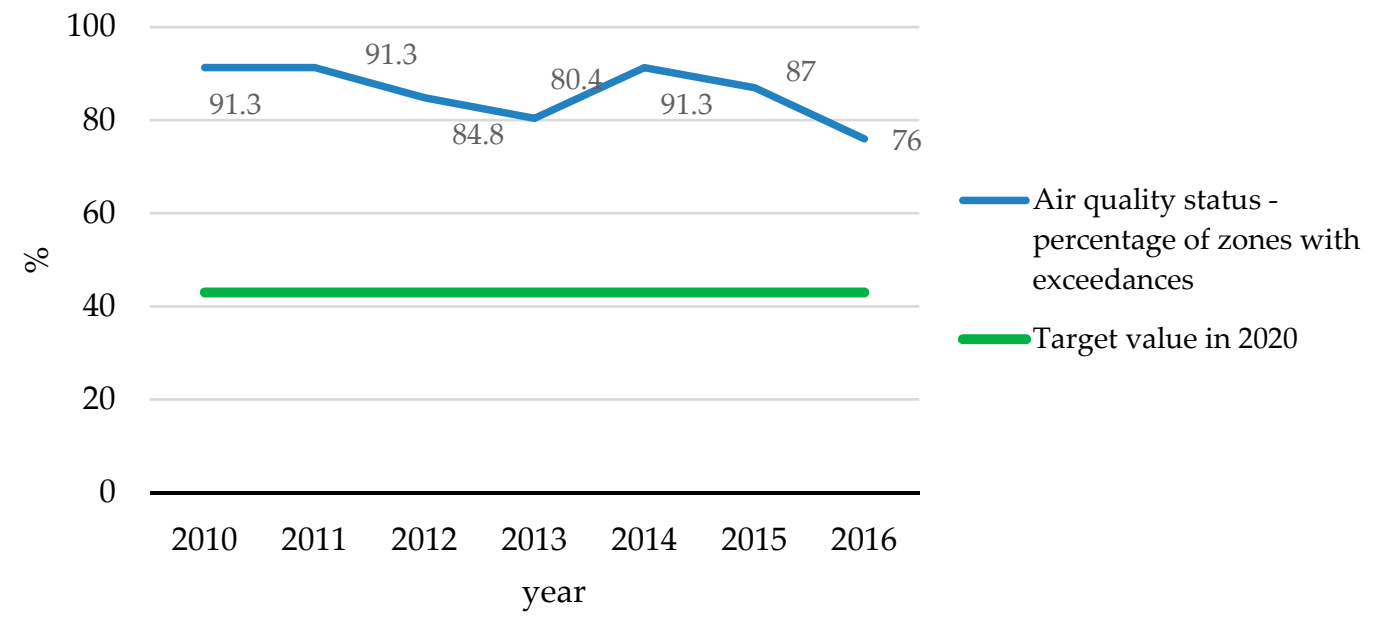

Figure 1. Air quality status in Poland-percentage of zones with exceedances.

This is of great importance because Poland is an infamous leader among the European Union countries in this respect. According to the WHO report, among the 50 most polluted European cities, as many as 33 are located in Poland, of which 7 out of the 10 most polluted cities in Europe are located in our country [11] (Figure 2).

The common persistence of such a condition has far-reaching negative consequences. Currently, 44 thousand people die annually as a result of air pollution in Poland [12], which means that 120 people die every day due to harmful dusts and chemical compounds in the air. Nitrogen oxides, carbon monoxides and PM10 and PM2.5 suspended particulateshave a negative effect on the functioning of the circulatory and respiratory systems, and prolonged exposure to them increases the likelihood of respiratory diseases, heart attack or stroke. This not only generates health costs for the society but also has financial implications, such as increased costs of medical care.

Excessive air pollution also translates into far-reaching climate changes in Poland, which may become even more noticeable in the coming years [13].

Of course, road transport is not the only source of air pollution, but it contributes significantly to the growth of adverse phenomena. According to data from the Institute of Environmental Protection, in 2017, in the national emission balance sheet, road transport was responsible for $37 \%$ of NOX, $23 \%$ of CO, $12 \%$ of NMVOCs, $8 \%$ of PM10 dusts, and $10 \%$ of PM2.5 dusts [14]. At the same time, it should be noted that the harmful substances emitted by the means of transport occupy the ground area where people are directly exposed to them.

Electric cars, due to their exclusive use of electric propulsion, emit small amounts of heat at their place of operation due to losses in energy conversion (Figure 3). 


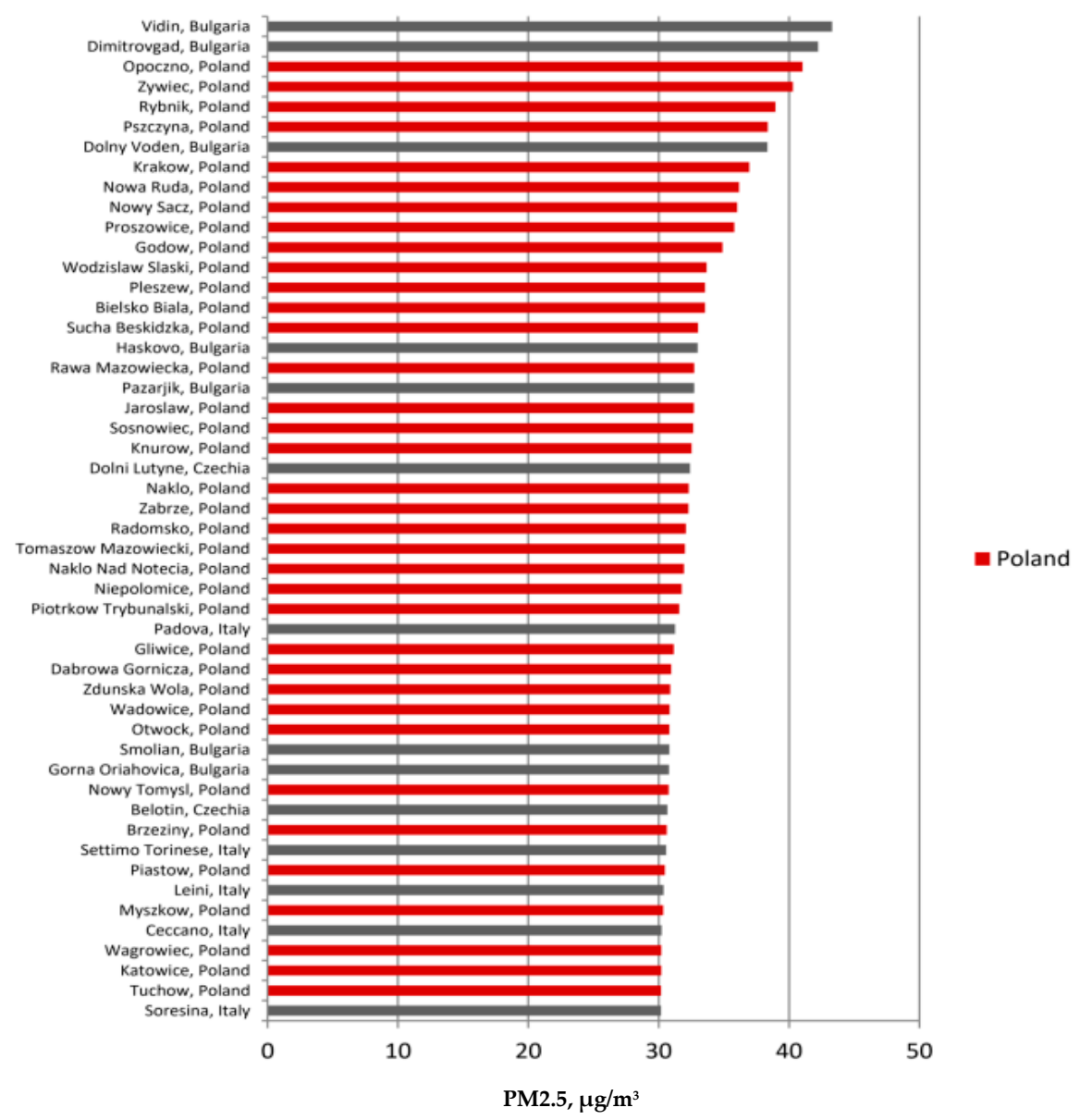

Figure 2. 50 most polluted cities in the European Union in 2019.

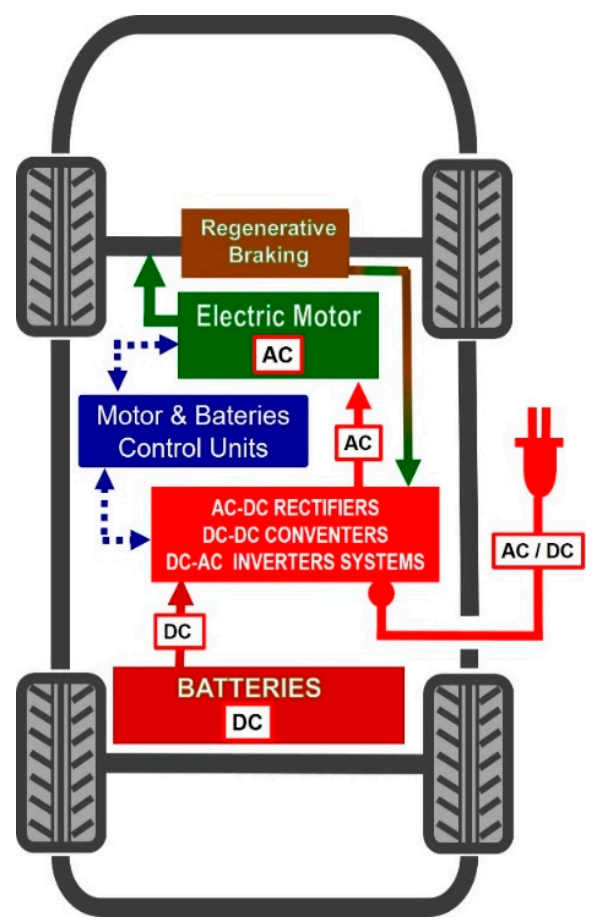

Figure 3. Battery Electric Vehicle (BEV) type electric car drive system. 
Therefore, in addition to eliminating low emission sources, electromobility is an opportunity to improve air quality, especially in cities, which should be treated as the main goal of implementing low emission means of transport [15-18].

An additional factor that will have a positive impact on the health of the residents will be the reduction of noise associated with transport in cities. Unfavorable health symptoms are observed with long-term exposure to noise from as low as $55 \mathrm{~dB}$, and in some large cities in Poland noise levels are even higher. The development of electromobility will significantly contribute to the reduction of noise originating from transport.

However, despite a number of advantages, electric cars in Poland still constitute a small share in the automotive market. The purpose of this article is to indicate why, despite a number of actions taken by the principals in the field of intensification of electromobility, e.g., in the form of a system of subsidies included in the Act on Electromobility and Alternative Fuels of 11 January 2018, the electric car market is still marginal in Poland.

\section{The State of Electromobilityin Poland and Subsidies in Place on the Market}

\subsection{Electric Car Market}

In order to assess the electrification of the transport sector in Poland, the data on the fleet of electric cars of type BEV, category M1 in the period 2011-2020 were initially analyzed.

The National Policy Framework for the Development of Alternative Fuel Infrastructure, which is an implementation of the EU Directive 2014/94/EU on the development of alternative fuel infrastructure, indicates that as a result of the implemented measures, which are to influence consumer behaviors towards the choice of low-emission transport sources, in 2020 and 2025, about 77 thousand and over 1 million electric cars will be registered in Poland, respectively (Table 1) [19].

Table 1. Planned number of BEVs in the National Policy Framework for Alternative Fuel Infrastructure Development.

\begin{tabular}{ccc}
\hline Year & Number of BEVs & New BEV Registrations \\
\hline 2015 & 1007 & - \\
2016 & 2397 & 138,966 \\
2017 & 5704 & 330,739 \\
2018 & 13,576 & 787,159 \\
2019 & 32,310 & $1,873,438$ \\
2020 & 76,898 & $4,458,783$ \\
2021 & 183,017 & $10,611,905$ \\
2022 & 366,034 & $18,306,191$ \\
2023 & 549,051 & $18,306,191$ \\
2024 & 823,576 & $27,452,536$ \\
2025 & $1,029,470$ & $20,589,402$ \\
\hline
\end{tabular}

Meanwhile, despite the fact that the number of newly registered electric cars powered exclusively by electricity is steadily growing from year to year (Figure 4), their number is currently 3954 (as of 10.20) and is $1.845 \%$ lower than that assumed in the National Policy Framework for the Development of Alternative Fuel Infrastructure (Figure 5). The share of such vehicles in the automotive market in Poland is currently 0.02\% (Figure 6) [20]. 


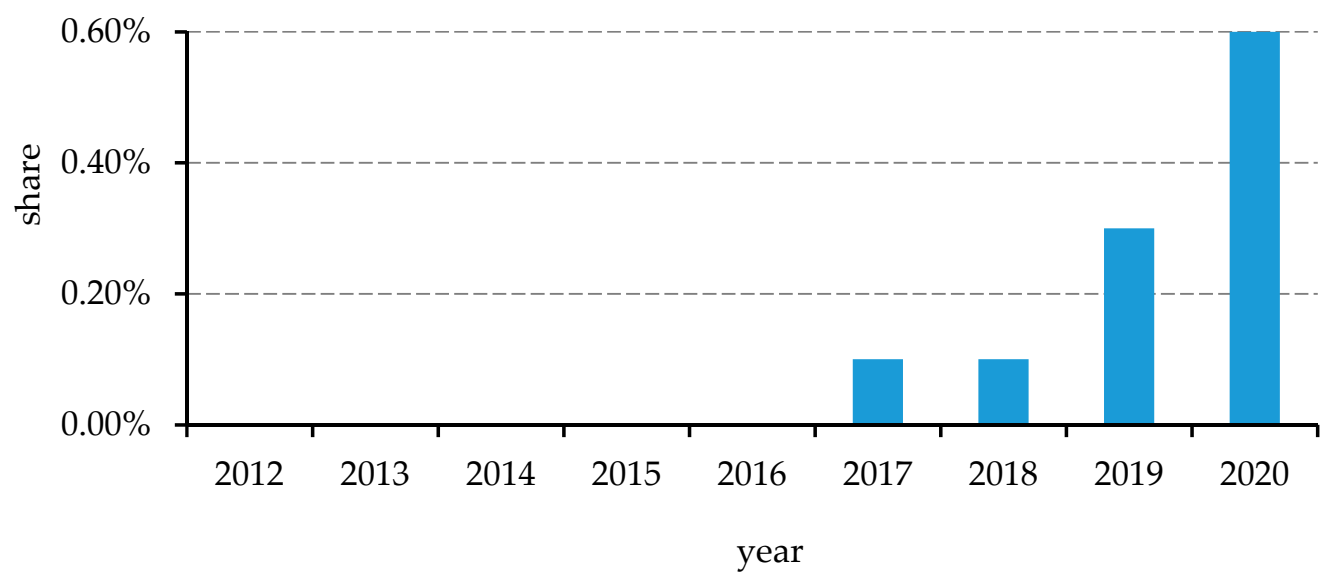

Figure 4. Share of new BEV registrations in Poland.

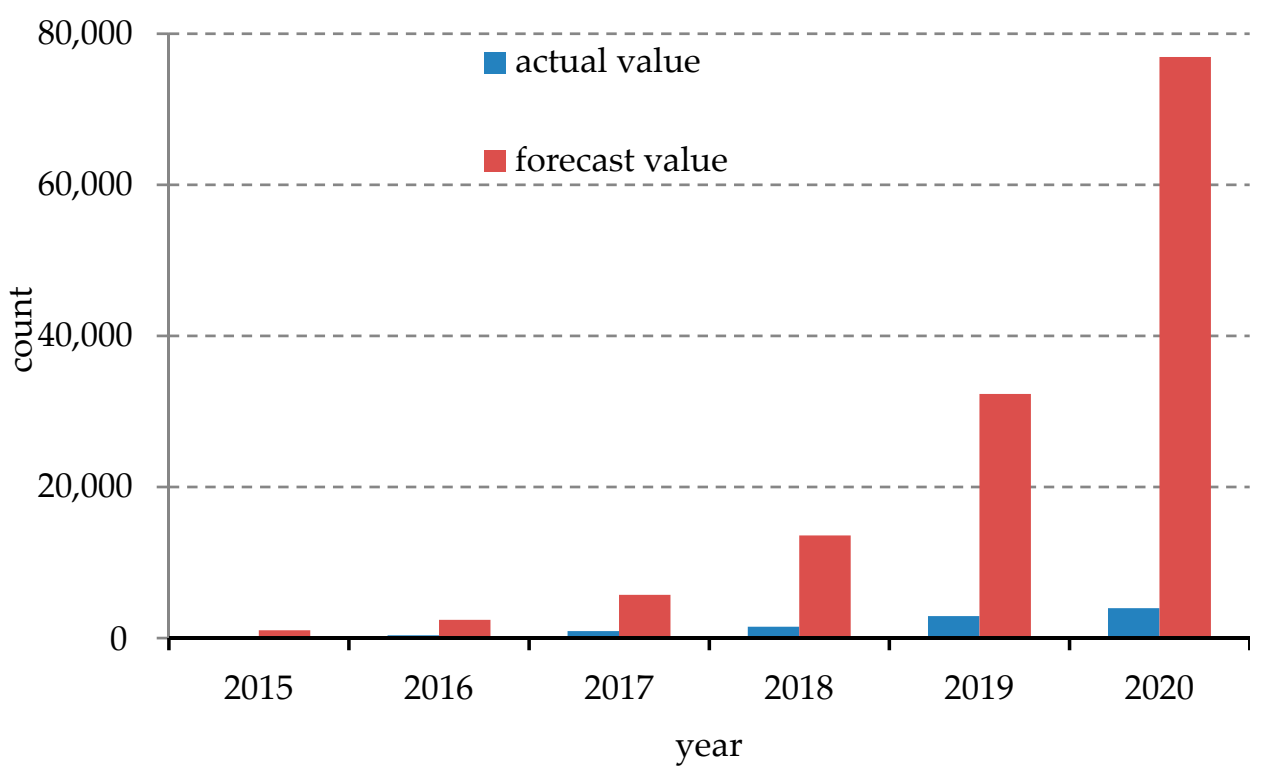

Figure 5. Total number of BEV vehicles in Poland.

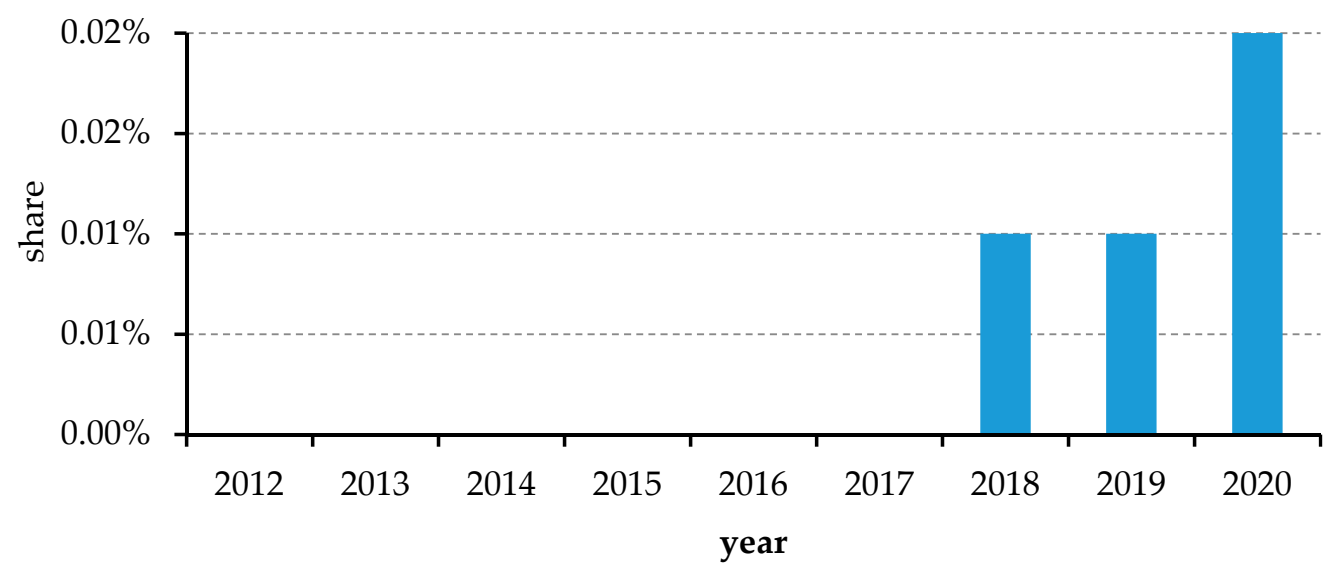

Figure 6. Share of BEV electric cars in the automotive market in Poland.

\subsection{Infrastructure for Charging Electric Vehicles}

The data quoted above indicate that the electric car market in Poland still accounts for a very small percentage of the entire automotive market. 
According to [21-25] and research conducted among Polish drivers [26-29], the reason for such low interest in electric cars is, among other things, the lack of sufficiently developed public charging infrastructure, even though about $70-80 \%$ of electric cars are charged at home, and the average daily car route (about $23 \mathrm{~km}$ according to the Motor Transport Institute) can be traveled without any additional recharging.

However, the fear that they will run out of power for further travel at some point of the road effectively discourages consumers from buying an electric car [30].

With this in mind, on 11 January 2018, the Sejm of the Republic of Poland passed the Act on Electromobility and Alternative Fuels, where Art. 60 imposed an obligation on local government units to launch appropriate infrastructure for charging electric cars by 31 March 2021 [6]. The minimum number of charging points in publicly accessible charging stations was determined there based on the demographic and transport characteristics of the commune (Table 2).

Table 2. Minimum number of charging outlets in publicly available charging stations in Poland (until 31 March 2021).

\begin{tabular}{cccc}
\hline Population & $\begin{array}{c}\text { Number of } \\
\text { Motor Vehicles }\end{array}$ & $\begin{array}{c}\text { Number of Motor } \\
\text { Vehicles per } \\
\text { 1000 Inhabitants }\end{array}$ & $\begin{array}{c}\text { Number of } \\
\text { Charging Outlets }\end{array}$ \\
\hline $1,000,000$ & $\geq 600,000$ & $\geq 700$ & 1000 \\
$>300,000$ & $\geq 200,000$ & $\geq 500$ & 210 \\
$>150,000$ & $\geq 95,000$ & $\geq 400$ & 100 \\
$>100,000$ & $\geq 60,000$ & $\geq 400$ & 60 \\
\hline
\end{tabular}

Analyzing the Central Statistical Office data for 2018 on the number of inhabitants and vehicles and referring to the guidelines contained in the above Act, public charging points need to be established according to the decision makers only in 32 out of 2477 communes in Poland (Table 3) [31].

Table 3. Minimum number of public charging points according to the Act of January 11, 2018 on Electromobility and Alternative Fuels.

\begin{tabular}{|c|c|c|c|c|c|}
\hline Voivodeship & Commune & Count & Voivodeship & Commune & Count \\
\hline $\begin{array}{l}\text { Lower } \\
\text { Silesian }\end{array}$ & Wroclaw & 210 & \multirow{11}{*}{ Silesian } & Bielsko-Biala & 100 \\
\hline Kuyavian- & Bydgoszcz & 100 & & Bytom & 60 \\
\hline Pomeranian & Torun & 100 & & Czestochowa & 100 \\
\hline Lublin & Lublin & 100 & & DabrowaGornicza & 60 \\
\hline \multirow[t]{2}{*}{ Lubusz } & $\begin{array}{c}\text { Gorzow } \\
\text { Wielkopolski }\end{array}$ & 60 & & Gliwice & 100 \\
\hline & Zielona Gora & 60 & & Katowice & 100 \\
\hline Lodzkie & Lodz & 210 & & RudaSlaska & 60 \\
\hline $\begin{array}{l}\text { Lesser } \\
\text { Poland }\end{array}$ & Cracow & 210 & & Rybnik & 60 \\
\hline \multirow{3}{*}{ Masovian } & Plock & 60 & & Sosnowiec & 100 \\
\hline & Radom & 100 & & Tychy & 60 \\
\hline & $\begin{array}{l}\text { Capital city } \\
\text { of Warsaw }\end{array}$ & 1000 & & Zabrze & 60 \\
\hline Opolskie & Opole & 60 & $\begin{array}{l}\text { Warmian- } \\
\text { Masurian }\end{array}$ & Olsztyn & 60 \\
\hline \multirow{2}{*}{$\begin{array}{l}\text { Subcarpathian } \\
\text { Podlaskie }\end{array}$} & Rzeszow & 100 & \multirow{2}{*}{$\begin{array}{l}\text { Greater } \\
\text { Poland }\end{array}$} & Kalisz & 60 \\
\hline & $\begin{array}{l}\text { Bialystok } \\
\text { Gdansk }\end{array}$ & $\begin{array}{l}100 \\
210\end{array}$ & & Poznan & 210 \\
\hline Pomeranian & Gdynia & 100 & West & Stettin & 210 \\
\hline Holy Cross & Kielce & 100 & Pomeranian & Stettın & 210 \\
\hline
\end{tabular}


All communes where public charging points are to be built are urban communes with a population of at least 100,975 .

Out of the 32 communes where, according to the Act, chargers should be built, only in one their minimum number should be 1000, in 6-210, in 13-100 and in 12 municipalities60. In total, according to the Legislator, at least 4280 public charging points are to be created.

The list of the number of communes with the minimum number of charging points is presented in Table 3.

When identifying communes in which, according to the Act of 11 January 2018 on Electromobility and Fuels, the minimum number of charging outlets is to be launched, based on the road distance between the seats of these communes, the distances between them were determined.

Figure 7 shows the distances between adjacent municipalities where, according to the Act of 11 January 2018 on Electromobility and Fuels, a minimum number of publicly accessible charging points is to be established.

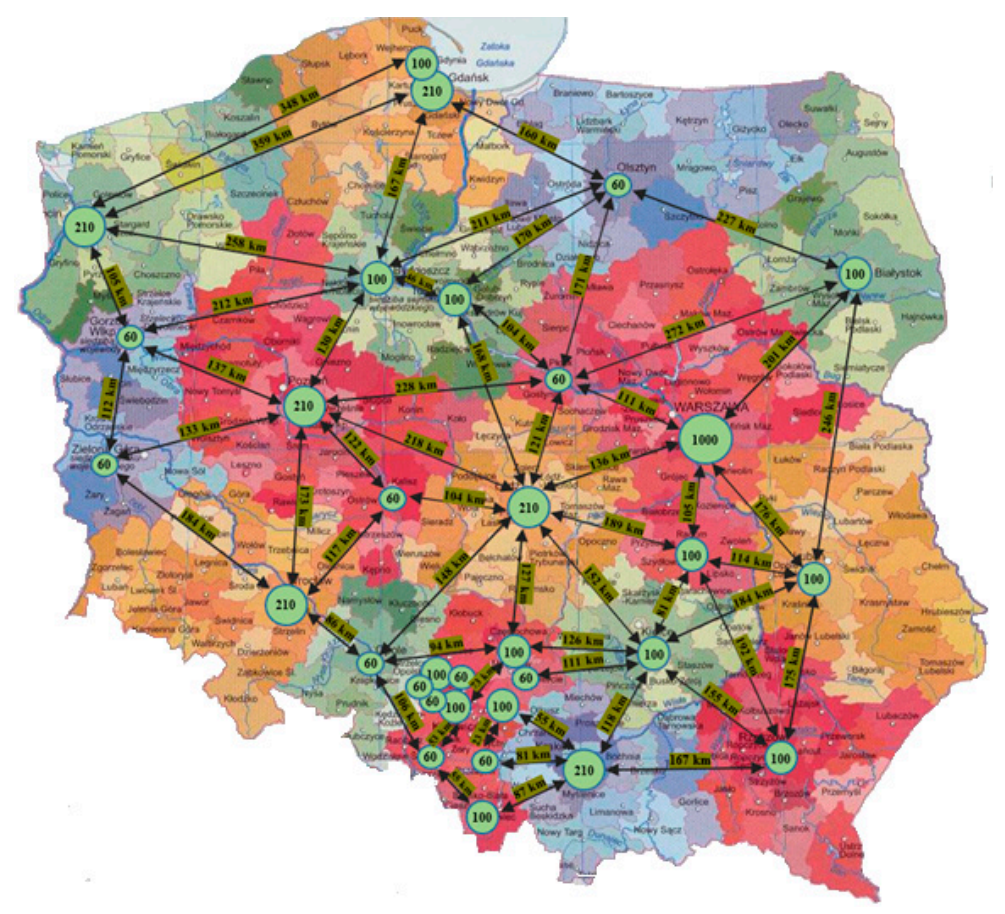

Figure 7. Minimum number of public charging points and distance between municipalities where they are to be located according to the Act of 11 January 2018 on Electromobility and Alternative Fuels.

The largest distance between such communes is $359 \mathrm{~km}$ (Gdańsk-Szczecin) and the smallest $10 \mathrm{~km}$ (Gliwice-Zabrze).

In the number of charging points installed in publicly accessible charging stations referred to in Section 1, the Legislator has taken into account the charging points located along the Trans-European Transport Network (TEN-T) [6].

In September 2018, the General Directorate for National Roads and Motorways published the Plan for Location of Publicly Available Charging Stations at Customer Service Areas on the TEN-T core network. According to the submitted Plan, by 31 March 2021, charging stations should be located at 159 Service Areas along A and S-class public national roads, i.e., along motorways and expressways (Table 4) [32-34]. 
Table 4. Planned number of charging stations along the TEN-T network in Poland.

\begin{tabular}{|c|c|c|c|c|c|c|c|c|c|c|c|c|c|}
\hline \multirow{2}{*}{$\begin{array}{l}\text { Road } \\
\text { Class }\end{array}$} & \multirow{2}{*}{ 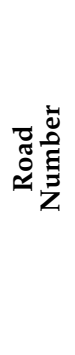 } & \multirow{2}{*}{ Direction } & \multirow{2}{*}{ 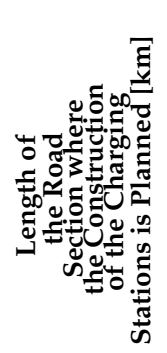 } & \multirow{2}{*}{ 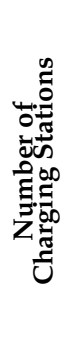 } & \multicolumn{3}{|c|}{$\begin{array}{l}\text { Distance between the } \\
\text { Locations of } \\
\text { Subsequent } \\
\text { Charging Points (km) }\end{array}$} & \multirow[t]{2}{*}{ Direction } & \multirow{2}{*}{ 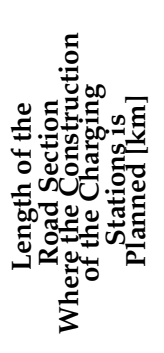 } & \multirow{2}{*}{ 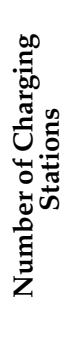 } & \multicolumn{3}{|c|}{$\begin{array}{l}\text { Distance between the } \\
\text { Locations of } \\
\text { Subsequent } \\
\text { Charging Points }(\mathrm{km})\end{array}$} \\
\hline & & & & & Mean & Min & Max & & & & Mean & Min & Max \\
\hline \multirow{4}{*}{ motorway } & 1 & South & 555.6 & 19 & 19.6 & 7.9 & 35.7 & North & 532.9 & 20 & 19.8 & 7.9 & 37.7 \\
\hline & 2 & East & 531.5 & 16 & 35.4 & 10.1 & 128.5 & West & 532.3 & 16 & 35.5 & 10.1 & 128.3 \\
\hline & 4 & East & 639 & 22 & 30.4 & 14.84 & 140 & West & 636.1 & 22 & 30.3 & 14.39 & 140.40 \\
\hline & 6 & East & 25.7 & 1 & - & - & - & West & 25.7 & 1 & - & - & - \\
\hline \multirow{5}{*}{ expressway } & 3 & South & 144.1 & 5 & 36 & 16.4 & 46.8 & North & 163.7 & 5 & 40.9 & 19.6 & 52.8 \\
\hline & 61 & South & 39.5 & - & - & - & - & North & 39.5 & 1 & - & - & - \\
\hline & 7 & South & 340 & 4 & 31.3 & 24 & 40 & North & 340 & 7 & 51.5 & 64.2 & 313.6 \\
\hline & 8 & East & 440.4 & 10 & 61.38 & 11.80 & 267.61 & West & 429.6 & 8 & 48.9 & 6.1 & 264 \\
\hline & 19 & South & 20.8 & 1 & - & - & - & North & 20.8 & 1 & - & - & - \\
\hline
\end{tabular}

Figure 8 shows the places where charging stations should be built according to the Act on Electromobilityand Alternative Fuels. The location of the charging stations along the TEN-T network is highlighted in green.

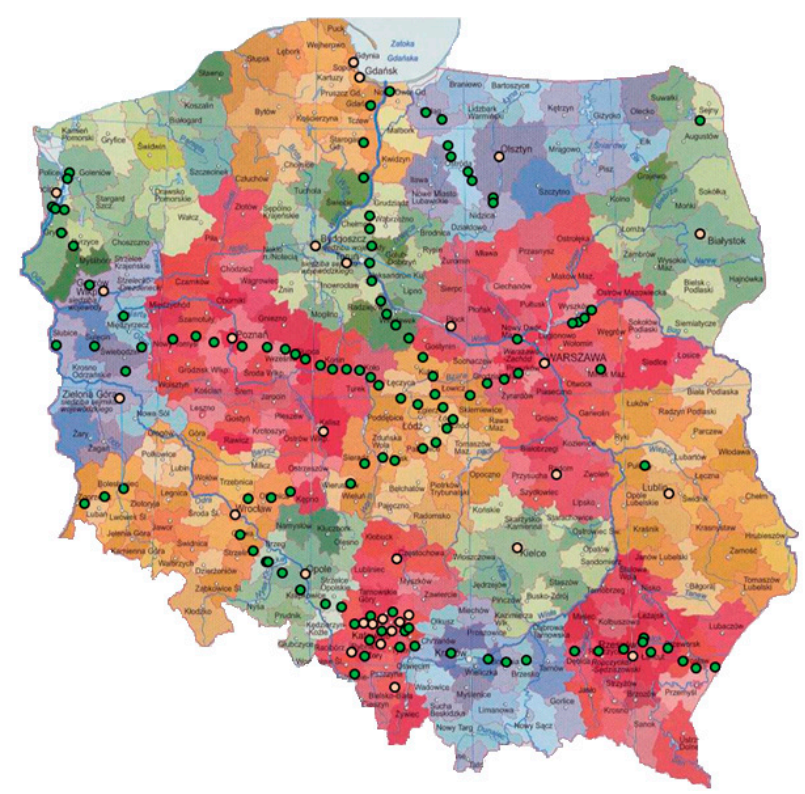

\section{MAP LEGEND}

O Distribution of EV charging sta-

tions in communes

OEV charging station locations

situated along the TEN-T

Figure 8. Location of charging points in Poland according to the Act of 11 January 2018 on electromobility and alternative fuels.

\subsection{Factors Stimulating Electromobility}

\subsubsection{Economic Subsidies}

Taking advantage of the experience of other countries, where the catalyst for the development of electromobility turned out to be instruments of financial support for purchasers of electric vehicles, on 26 June 2020 the National Fund for Environmental Protection and Water Management and the Ministry of Climate launched the only program for individual customers so far-“"Green Car-co-financing of the purchase of an electric 
passenger car (M1)", under which it was possible to apply for funding for the purchase of an entirely electric, brand new passenger car from the M1 category. The vehicles purchased may not be used for business activities within the meaning of EU competition law, including farming activities. Moreover, they cannot be entered in the register of fixed assets used in business activity.

The support was provided in the form of a grant and its maximum amount was 18,750 PLN (twice less than assumed in the program prepared earlier by the Ministry of Energy) or up to $15 \%$ of eligible costs. The Ministry of Climate has also set an upper price limit for the supported vehicle. Its height was set at PLN 125 thousand.

\subsection{2. "Soft" Support Mechanisms}

An important benefit for the development of the electromobility market in Poland is also to be the application of non-financial—so called soft support-mechanisms for users of electric cars in the form of free parking, the possibility of using bus lanes or entering low-emission zones.

Section 1 of Article 39 of the Act on Electromobility and Alternative Fuels indicated that in a commune with more than 100,000 inhabitants, for the area of downtown development or part thereof, being a grouping of intensive development in the area of downtown, specified in the local spatial development plan, and in case of its absence in the study of conditions and directions of the municipality's spatial development, a zone of clean transport can be established in an area including roads managed by the commune, to which the entry of non-electric, hydrogen-powered vehicles, powered by natural gas (combustion plants whose (combustion of which (residual amounts of sulfur contamination) reduces SOx emissions, but also causes $\mathrm{CO}_{2}$ emissions as a greenhouse gas) is limited.

Another privilege granted to users of BEV electric vehicles is the possibility of free parking in ametered parking zone [6] and no additional car identification, i.e., stickers or signs, is required for this.

Another stimulus designed to encourage drivers to use electric cars in Poland is the possibility to drive such a vehicle along bus lanes designated by the road manager until 1 January 2026 [35].

\section{Discussion}

One of the main factors inhibiting the development of the so-called zero-emission transport are the high costs of purchasing electric cars in comparison with their internal combustion equivalents [36-40]. In order to reduce this difference, governments of many countries, including Poland, are introducing a system of financial support for electromobility.

The one launched in Poland in the form of the program "Green Car-co-financing of the purchase of an electric passenger car (M1)" proved to be unattractive. According to the announced results, 262 individual applications were registered for the total amount of funding of PLN 4,586,138, although the program's budget provided for the possibility of providing such assistance to at least 2000 people for a total of PLN 37.5 million.

Such a low interest in funding resulted from the relatively low value of the surcharge and the low limit of the maximum price of the vehicle that could be covered by the funding, which meant that those interested in buying electric cars had only eight models to choose from at that time (Table 5).

Another reason for such low interest in grants is the actual payment of the granted support, which will be made after the beneficiaries provide appropriate documents, in particular, confirming the purchase of the vehicle for which support was granted. Not only did private individuals who bought an electric car had to pay the full amount for the vehicle, but they were not aware of the support they would receive.

Another factor that has a particularly strong impact on the development of the electric car market is considered to be the extensive, generally available charging infrastructure. 
Table 5. Models of electric vehicles eligible for subsidy under the "Green Car-co-financing of the purchase of an electric passenger car (M1)" program (as of June 2020).

\begin{tabular}{cccc}
\hline Vehicle Model & Catalog Price (PLN) & $\begin{array}{c}\text { Price after Subsidy } \\
\text { (PLN) }\end{array}$ & $\begin{array}{c}\text { Amount of the } \\
\text { Subsidy (PLN) }\end{array}$ \\
\hline smart EQ fortwo & 96,900 & 82,365 & 14,535 \\
Volkswagen e-up & 97,990 & 83,291 & 14,698 \\
smart EQ forfour & 98,400 & 83,640 & 14,760 \\
smart EQ forfour & 110,700 & 94,095 & 16,605 \\
convertible & 118,000 & 100,300 & 17,700 \\
Nissan LEAF & 124,490 & 105,816 & 18,673 \\
Opel Corsa-e & 124,900 & 106,165 & 18,735 \\
Peugeot e-208 & 124,900 & 106,165 & 18,735 \\
Renault ZOE & & & \\
\hline
\end{tabular}

Meanwhile, taking into account the location indicated in the Act on Electromobility and Alternative Fuels of 11 January 2018 and the minimum number of publicly available charging points in Poland to be created by 31 March 2021 (According to the Act, the distance between the communes where the minimum number of public charging points is to operate will at one point reach $359 \mathrm{~km}$ ), it will not be sufficient to ensure the comfortable use of electric cars and the already existing significant disparities in the number of charging points between agglomerations and smaller towns and rural areas will be further widened.

It is estimated that in 2019 in Poland, 49\% of charging stations were operating in larger cities (Figure 9) [41-43].

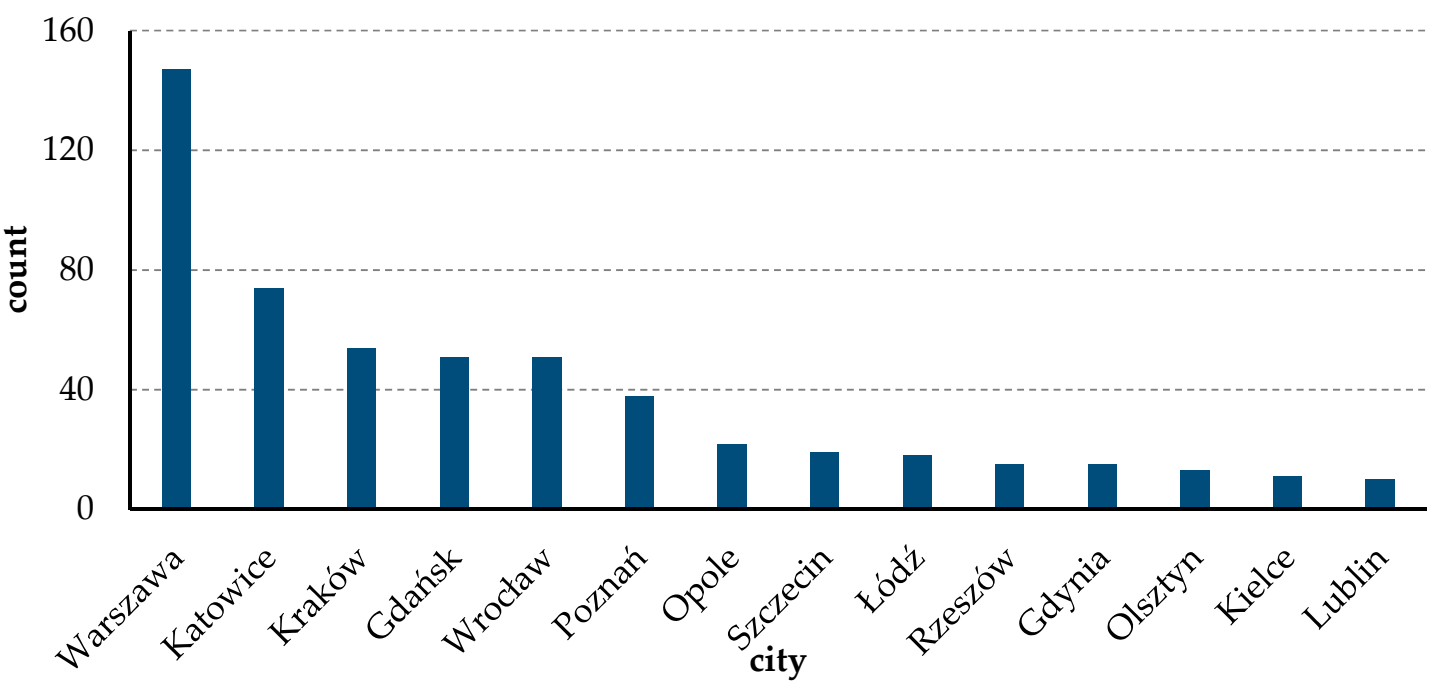

Figure 9. Cities in Poland with the highest number of charging stations in 2019 (pcs.).

Although the Legislator has taken into account the construction of charging stations along public roads, they will be located only along 9 out of 98 national roads.

So there will still be areas where the number of public chargers is negligible or there will be none (Figure 10). Meanwhile, according to Polish drivers, the ideal electric car should be produced in Poland, accommodate four people, and have a $150 \mathrm{~km}$ range with the possibility of recharging every $50 \mathrm{~km}$ [44]. 


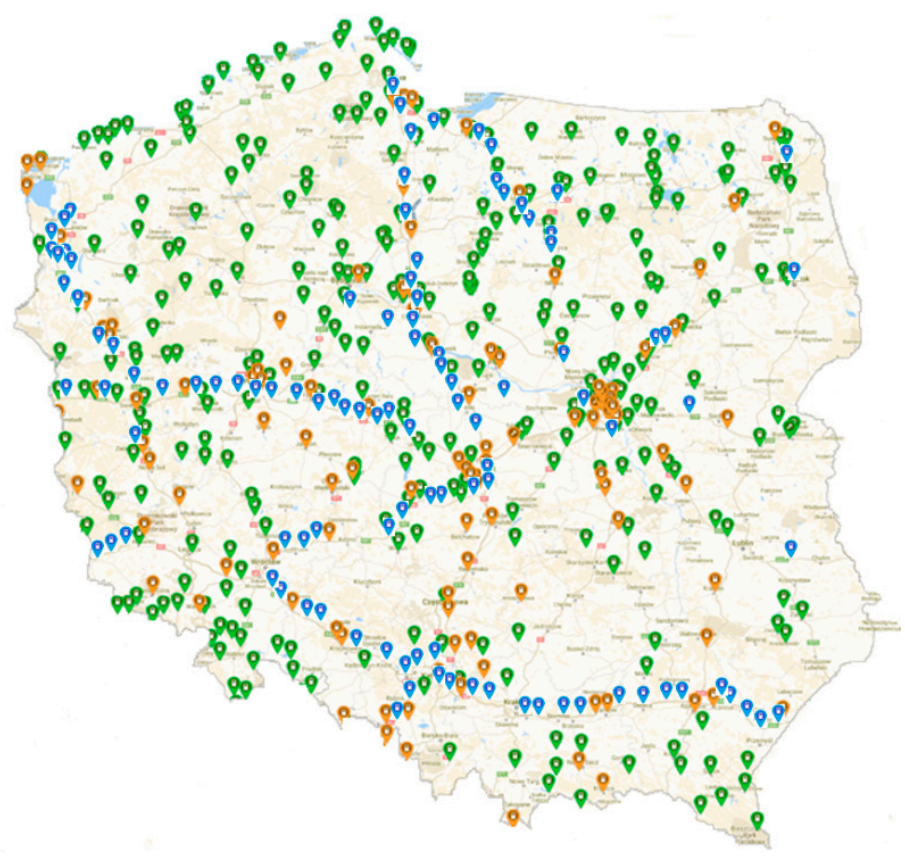

Figure 10. Map of charging points in Poland-as of 31 March 2021 according to the Act of 11 January 2018 on electromobility and alternative fuels.

Taking into account the existing charging infrastructure [45] and the assumptions of the Act of 11 January 2018 on Electromobility and Alternative Fuels, in March 2021 there should be 4280 public charging points in Poland (according to [46] the number of fuel stations in Poland on 30.09.20-7720), which means that their number should increase by $250 \%$ in relation to their number in 2019 . This is unlikely, due to numerous administrative and fiscal barriers. These include long waiting time, often reaching several months, for the connection of stations to the power network, limitations in the possibility of network development (e.g., in road lanes, which results from the provisions of the Act on Roads), lack of regulations enabling the acquisition of the so-called right of way for new lines (lack of the Act on Transmission Corridors), or high distribution fees, which particularly burden Polish operators in comparison with similar entities operating in other European Union member states.

Another extremely important factor related to the charging infrastructure is to provide access to charging stations to residents of multi-family buildings. It is of key importance in this area to implement into the Polish legal order the EU regulations (the so-called Buildings Directive), which would impose obligations on developers to ensure the connection conditions for chargers, which have not been implemented so far.

Another privilege that is supposed to motivate Poles to use electric cars is the possibility of entering low-emission zones and driving in bus lanes.

So far, the only city in Poland that has introduced a clean transport zone has been Krakow, and in the required shape it was valid for only two months. It was protested by residents and businessmen conducting business on its territory, as a result of which it was replaced with a restricted traffic zone, which made it practically irrelevant. The local authorities have extended the possibility of entry to the supplier zone to $10 \mathrm{~h}$ a day and allowed access from 9:00 to 17:00 for any vehicle whose driver informs that they are a customer or counterparty of any company operating in the zone.

Until 2026, drivers of electric cars can drive such a vehicle in the lanes designated by the road manager for buses.

There were $299.5 \mathrm{~km}$ of bus lanes in Poland in 2019 and their length over the last six years (2013-2019) increased on average by $9.2 \%$ year to year (Figure 11). 


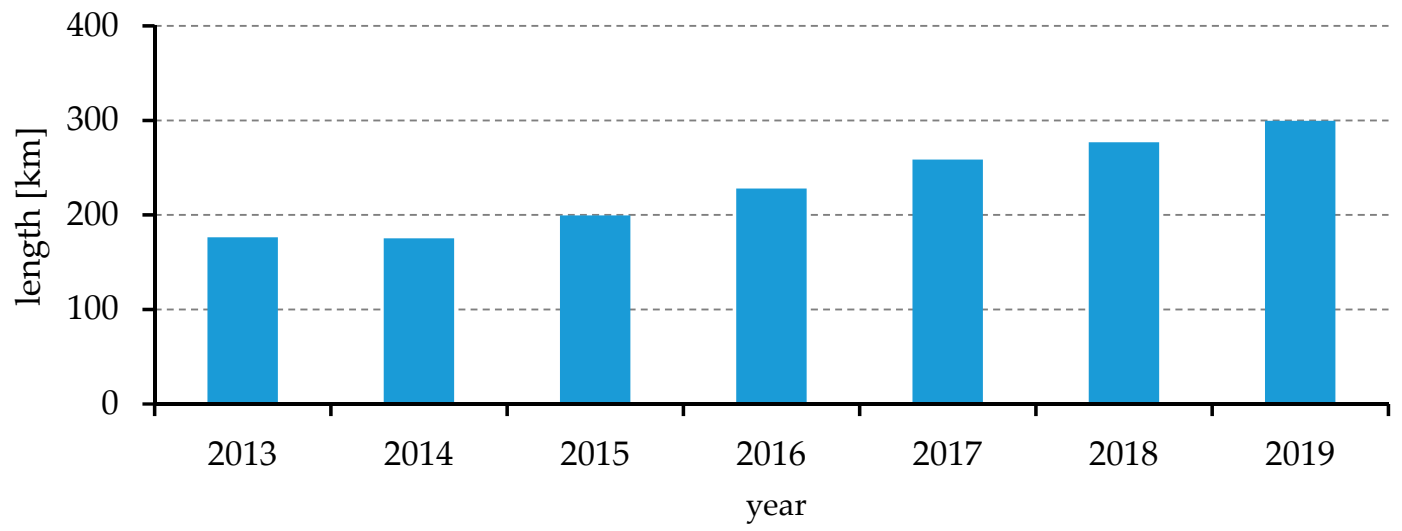

Figure 11. Total length of bus lanes in Poland.

More than half of the bus lanes, i.e., $151.4 \mathrm{~km}$, are allotted out only in four cities: Warsaw, Kraków, Wrocław, and Łódź, of which $68.9 \mathrm{~km}(46 \%)$ is located in Warsaw (Figure 12).

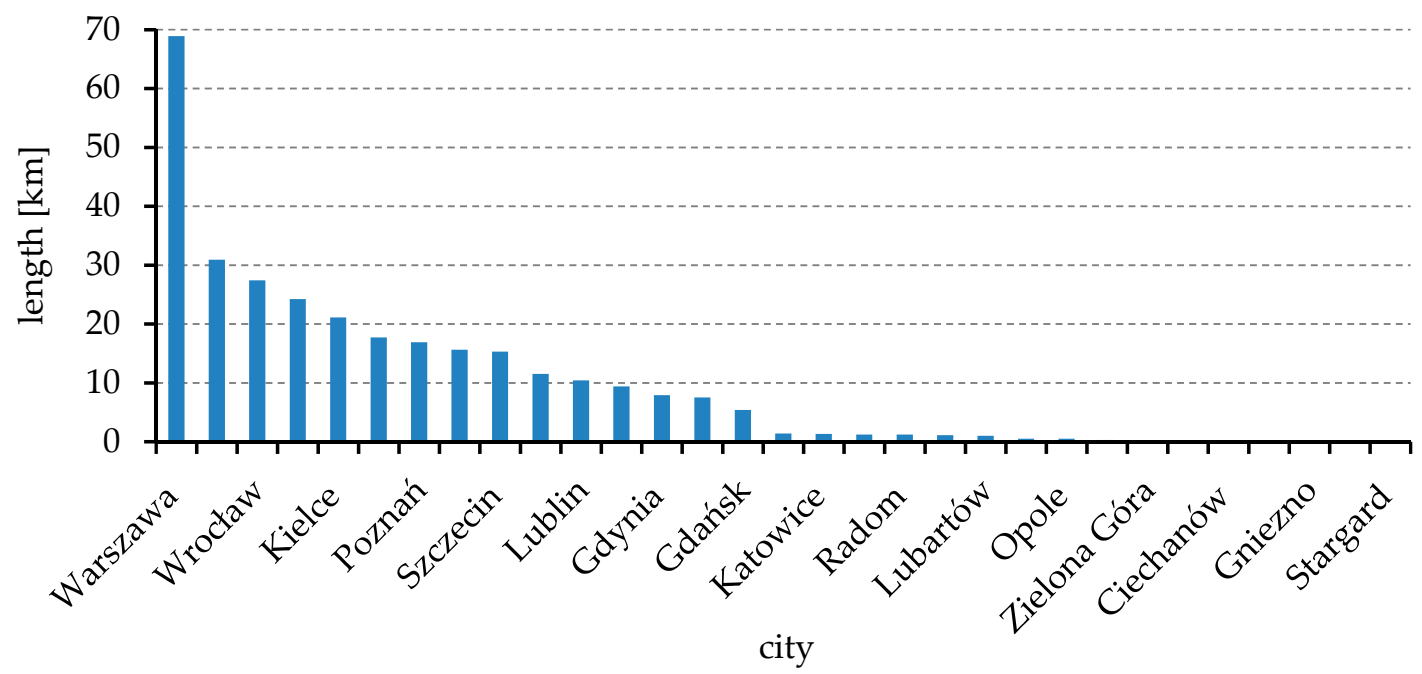

Figure 12. Bus lanes in Poland.

Thus, electric car drivers enjoy the privilege of driving in bus lanes, as long as they are in the four largest cities.

An additional obstacle to the use of bus lanes may be that in many places it is difficult to enter and exit the bus lanes due to traffic restrictions or congestion on the other lanes. In addition, they are often strictly delineated under bus routes (which can de facto slow down traffic on the lane by having to stand at stops) and do not form a coherent network. Moreover, the mere marking of such lanes is ambiguous and often misleads traffic participants. It is not always obvious whether only buses or other bus lane users can follow this route.

For example, the road sign F-10 (Figure 13) informs that the right lane is intended only for buses or trolleybuses and other vehicles that carry people on regular lines for a fee [35]. There is no clear information there that an electric vehicle can also run on such a lane. 


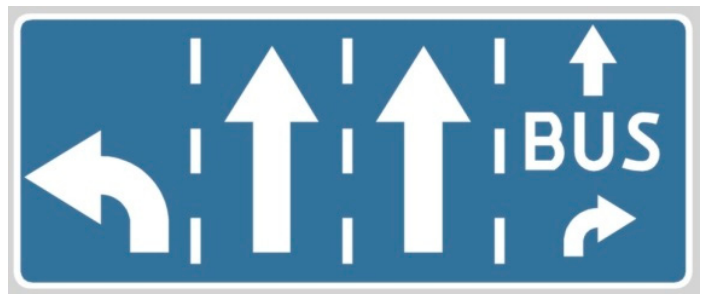

Figure 13. Supplementary sign F-10.

Another difficulty is that the law enforcement agencies and other users of the bus lane are not always fully aware of the changes.

\section{Conclusions}

Analyzing the system of factors currently operating in Poland that are supposed to motivate consumers to buy electric cars, it should be considered as ineffective. None of the actions that have been introduced by decision-makers, such as the indication of the number and location of the charging stations, the purchase subsidies are not effective enough to influence the dynamics of the electromobility market.

The "Green Car-co-financing of the purchase of an electric passenger car (M1)" subsidy offered in the program is so small that it does not meet the needs of the market and does not meet the needs of consumers. In Poland, in 2019, the automotive market was made up of more than $70 \%$ of at least 10 year old passenger cars with an average purchase price of PLN 18 thousand, of which 65\% was purchased for less than PLN 30 thousand [47]. Meanwhile, the cheapest electric car, i.e., a two-person smart EQ fortwo, after obtaining the maximum amount of support, costs the buyer PLN 82,365.

It seems reasonable to introduce the following before the prices of electric cars come close to the level of prices of vehicles with traditional propulsion, among other things, thanks to the development of the battery market:

- greater co-financing for their purchase,

- tax reliefs, i.e., significant reduction of the vehicle price already at the time of purchase,

- return of a part of the purchase costs incurred after previous purchase of an electric car at the normal catalog price,

- attaching wall chargers to cars that can be installed in customers' homes,

- free passage through motorways managed by the General Directorate for National Roads and Motorways (GDDKiA),

It is also advisable to support the construction and operation of publicly available charging stations, especially on major traffic routes (national roads, expressways, and motorways), including primarily high-powered chargers that reduce the waiting time for the vehicle to recharge. Therefore, support should vary according to the type of charger to encourage investors to expand their high-power charging point network. The process of building a charging station involves many entities and requires a lot of formalities, therefore, it is reasonable for the principals to create mechanisms to support the construction and operation of publicly available electric car charging stations, such as the creation of a special distribution tariff, the facilitate the procedures so that they do not adversely affect the project the creation of a special distribution tarif.

A confirmation of how much the implemented incentives can affect the development of the infrastructure of electric cars was the tax reduction introduced in 2014 in France for companies that will install a charging point in their buildings. The adopted solution has brought the intended effects, as already in 2015, the number of chargers has increased by $482 \%$ compared to 2014 [48].

It should be emphasized here that all solutions implemented by the principals must be characterized by the greatest possible simplicity and ease of use. It is not possible to popularize a solution that would be more difficult for the consumer's use than the 
current one (and refueling of an internal combustion vehicle is widely available and not very complicated).

Author Contributions: Conceptualization-E.S.-M.; methodology-E.S.-M.; validation-E.S.-M.; formal analysis-E.S.-M., Z.Ł.; investigation-E.S.-M., Z.Ł.; resources-E.S.-M.; data curationE.S.-M.; writing—original draft preparation-E.S.-M., Z.Ł.; writing—review and editing-E.S.-M.; visualization- E.S.-M., Z.Ł.; supervision-E.S.-M.; funding acquisition-E.S.-M. All authors have read and agreed to the published version of the manuscript.

Funding: This research received no external funding.

Institutional Review Board Statement: Not applicable.

Informed Consent Statement: Informed consent was obtained from all subjects involved in the study.

Conflicts of Interest: The authors declare no conflict of interest.

\section{References}

1. Communication from the Commission, Europe 2020, A Strategy for Smart, Sustainable and Inclusive Growth. Available online: https:/ / ec.europa.eu/eu2020/pdf/COMPLET\%20EN\%20BARROSO\%20\%20\%20007\%20-\%20Europe\%202020\%20-\%2 0EN\%20version.pdf (accessed on 29 October 2020).

2. White Paper on Transport, Roadmap to a Single European Transport Area-Towards a Competitive and Resource-Efficient Transport System. Available online: https:/ / ec.europa.eu/transport/sites/transport/files/themes/strategies/doc/2011_white_ paper/white-paper-illustrated-brochure_en.pdf (accessed on 29 October 2020).

3. Directive 2014/94/EU of the European Parliament and of the Council of 22 October 2014 on the Deployment of Alternative Fuels Infrastructure. Available online: https:/ / eur-lex.europa.eu/legal-content/EN/TXT/PDF/?uri=CELEX:32014L0094 (accessed on 29 October 2020).

4. Communication from the Commission to the European Parliament, the Council, the European Economic and Social Committee and the Committee of the Regions a European Strategy for Low-Emission Mobility. Available online: https: / / eur-lex.europa.eu/ legal-content/en/ALL/?uri=CELEX:52016DC0501 (accessed on 29 October 2020).

5. The Strategy for Responsible Development for the Period up to 2020 (Including the Perspective up to 2030). Available online: https: / / www.miir.gov.pl/media/48672/SOR.pdf (accessed on 29 October 2020).

6. Act of 11 January 2018 on Electromobility and Alternative Fuels. Available online: https://isap.sejm.gov.pl/isap.nsf/download. xsp/WDU20180000317/T/D20180317L.pdf (accessed on 29 October 2020).

7. Electromobility in Poland. Available online: https://www.gov.pl/web/aktywa-panstwowe/elektromobilnosc-w-polsce (accessed on 29 October 2020).

8. Vassileva, I.; Campillo, J. Adoption barriers for electric vehicles: Experiences from early adopters in Sweden. Energy 2017, 120, 632-641. [CrossRef]

9. Egbue, O.; Long, S. Barriers to widespread adoption of electric vehicles: An analysis of consumer attitudes and perceptions. Energy Policy 2012, 48, 717-729. [CrossRef]

10. STRATEG. Available online: https://strateg.stat.gov.pl/\#/ (accessed on 29 October 2020).

11. World Health Organization. Available online: https://www.euro.who.int/en/health-topics/environment-and-health/airquality / data-and-statistics (accessed on 29 October 2020).

12. The Government Has Adopted the Electromobility Development Plan in Poland. Available online: http://www.pap.pl/ aktualnosci/news,530342, eksperci-liczba-osob-z-przewleklymi-chorobami-pluc-bedzie-rosla.html (accessed on 27 October 2020).

13. The State Ecological Policy 2030. Available online: https://bip.mos.gov.pl/fileadmin/user_upload/bip/strategie_plany_ programy/Polityka_Ekologiczna_Panstwa/Polityka_Ekologiczna_Panstwa_2030.pdf (accessed on 27 October 2020).

14. The National Emission Balance of SO2, NOx, CO, NH3, NMVOC, Dust, Heavy Metals and POPs for 2015-2017. Available online: https:/ / www.kobize.pl/uploads/materialy/materialy_do_pobrania/krajowa_inwentaryzacja_emisji/Bilans_emisji_za_ 2017.pdf (accessed on 27 October 2020).

15. Helmers, E.; Marx, M. Electric cars: Technical characteristics and environmental impacts. Environ. Sci. Eur. 2012, 24, 2-15. [CrossRef]

16. Muniamuthu, S.; Arjun, K.S.; Jalapathy, M.; Harikrishnan, S.; Vignesh, A. Review on Electric Vehicles. Int. J. Mech. Prod. Eng. Res.Dev. 2018, 8, 557-566.

17. Chudy, A.; Mazurek, P.A. Electromobility—the Importance of Power Quality and Environmental Sustainability. J. Ecol. Eng. 2019, 20, 15-23. [CrossRef]

18. Croce, A.I.; Musolino, G.; Rindone, C.; Vietta, A. Sustainable mobility and energy resources: A quantitative assessment of transport services with electrical vehicles. Renew. Sustain. Energy Rev. 2019, 113, 1-13. [CrossRef]

19. National Policy Framework for the Development of Alternative Fuels Infrastructure. Available online: https://www.gov.pl (accessed on 27 October 2020). 
20. European Alternative Fuels Observatory. Available online: https://www.eafo.eu/ (accessed on 27 October 2020).

21. Zaniewska-Zielińska, D. Electromobility development problems in Poland. Eur. Reg. 2018, 2, 63-78. [CrossRef]

22. Krawiec, S.; Krawiec, K. Electromobility development in Poland. Conditions, objectives and barriers. Zesz. Nauk. Uniww. Ekon. Katowicach 2017, 332, 17-24.

23. Sendek-Matysiak, E.; Szumska, E. Charging infrastructure as one of electromobility development elements in Poland. Pr. Nauk. Politech. Warsz. 2018, 121, 329-340.

24. Wierzbowski, P. Electric-fuelled road transport as element of logistic support system-Electromobility development perspectives in Poland. Logistyka 2019, 9, 38-59.

25. Sendek-Matysiak, E. Most import ant barriers for electromobility development in Poland. Przegląd Komun. 2020, 3, 8-15.

26. Polish Alternative Fuels Association. Available online: http://pspa.com.pl/en (accessed on 27 October 2020).

27. Innogy. Available online: https://www.innogy.pl/ (accessed on 27 October 2020).

28. Electro Mobility Poland. Available online: https:/ / electromobilitypoland.pl/ (accessed on 27 October 2020).

29. KPMG. Automotive Industry against the Current. Assessment of Electromobility Development Support Forms in Poland, within the Framework of the Low-Emission Transport Fund. Available online: https://home.kpmg/pl/pl/home.html (accessed on 27 October 2020).

30. Jakobsson, N.; Gnann, T.; Plötz, P.; Sprei, F.; Karlsson, S. Are multi-car households better suited for battery electric vehicles?Driving patterns and economics in Sweden and Germany. Transp. Res. Part CEmerg. Technol. 2016, 65, 1-15. [CrossRef]

31. Central Statistical Office. Available online: https://stat.gov.pl/ (accessed on 27 October 2020).

32. General Directorate for National Roads and Motorways. Available online: https://www.gddkia.gov.pl/ (accessed on 27 October 2020).

33. Targeo.pl. Available online: https://www.targeo.pl/ (accessed on 27 October 2020).

34. Google Maps. Available online: https://www.google.pl/maps/ (accessed on 27 October 2020).

35. Road Traffic Law. Available online: http://isap.sejm.gov.pl/isap.nsf/home.xsp (accessed on 27 October 2020).

36. Cherchi, E. A stated choice experiment to measure the effect of informational and normative conformity in the preference for electric vehicles. Transp. Res. Part A Policy Pract. 2017, 100, 88-104. [CrossRef]

37. Van Der Straten, P.; Wiegmans, B.W.; Schelling, A.B. Enablers and barriers to the adoption of alternativelypoweredbuses. Transp. Rev. 2007, 27, 679-698. [CrossRef]

38. Schneidereit, T.; Franke, T.; Günther, M.; Krems, J.F. Does range matter? Exploring perceptions of electricvehicles with and without a range extender among potential early adopters in Germany. Energy Res. Soc. Sci. 2015, 8, 198-206. [CrossRef]

39. Noel, L.; de Rubens, G.Z.; Sovacool, B.K.; Kester, J. Fear and loathing of electric vehicles: The reactionary rhetoric of range anxiety. Energy Res. Soc. Sci. 2019, 48, 96-107. [CrossRef]

40. She, Z.Y.; Qing, S.; Ma, J.J.; Xie, B.C. What are the barriers to widespread adoption of battery electric vehicles? A survey of public perception in Tianjin, China. Transp. Policy 2017, 56, 29-40. [CrossRef]

41. Central Register of Vehicles. Available online: http://www.cepik.gov.pl/ (accessed on 27 October 2020).

42. Polish Automotive Industry Association. Available online: www.pzpm.org.pl (accessed on 27 October 2020).

43. High Voltage.pl. Available online: https://wysokienapiecie.pl (accessed on 27 October 2020).

44. Kantar TNS. Available online: http:/ / www.tnsglobal.pl/ (accessed on 27 October 2020).

45. PlugShare-EV Charging Station Map. Available online: https://www.plugshare.com/ (accessed on 27 October 2020).

46. Polish Organisation of Oil Industry and Trade. Available online: http://www.popihn.pl/ (accessed on 27 October 2020).

47. Automotive Industry Report 2020/2021. Available online: https://www.pzpm.org.pl/Publikacje/Raporty/Raport-branzymotoryzacyjnej-2020-2021 (accessed on 27 October 2020).

48. Sendek-Matysiak, E. Assessment of the condition of road transport infrastructure in Poland in 2000-2015 by drivers. PraceNauk. Politech. Warsz. 2017, 117, 331-341. 